\title{
Micronephthys (Polychaeta: Nephtyidae) of Northern Europe and Arctic
}

\author{
N.Yu. Dnestrovskaya, I.A. Jirkov \\ Moscow State University, Biological Faculty, Department of Hydrobiology; Leninskie Gory, 1, \\ bldg. 12, Moscow 119991, Russia \\ e-mail:ndnestro@mail.ru
}

ABSTRACT: Three species of Micronephthys inhabit Northern European and Arctic waters: Micronephthys minuta (Theel, 1879), M. neotena (Noyes, 1980), and M. hartmannschroederae Jirkov et Dnestrovskaya, 2001. All species are re-described, original illustrations and distribution maps accompany all descriptions. Micronephthys minuta and M. neotena are a mainly Arctic and boreal species, respectively, very abundant in brackish waters. Micronephthys hartmannschroederae should be very abundant sporadically in boreal European waters. The existing literature on biology and distribution of these species is reviewed. The taxonomic characters used to separate genera within Nephtyidae are analysed, proving that the family needs to be fully reviewed.

KEY WORDS: Polychaeta, Nephtyidae, Micronephthys, Northern Europe, Arctic.

\section{Micronephthys (Polychaeta: Nephtyidae) северной Европы и Арктики}

\section{Н.Ю. Днестровская, И.А. Жирков}

\author{
Московский государственный университет им. М.В. Ломоносова, Биологический факуль- \\ тет, кафедра гидробиологии; Ленинские горы, 1, стр. 12, Москва 119991, Россия. \\ e-mail: ndnestro@mail.ru
}

РЕЗЮМЕ: Из морей северной Европы и Арктики известно три вида Micronephthys: Micronephthys minuta (Theel, 1879), M. neotena (Noyes, 1980) и M. hartmannschroederae Jirkov et Dnestrovskaya, 2001. Даны иллюстрированные переописания всех трёх видов и карта всех известных находок. M. minuta и M. neotena очень обычны в распреснённых водах, первый - преимущественно в Арктике, второй — в бореальных водах. M. hartmannschroederae должен быть очень обычным в европейских бореальных водах. Дан обзор особенностей распространения и биологии. Кратко обсуждена значимость таксономических признаков, использующихся для разделения родов Nephtyidae, показана необходимость полной ревизии всего семейства.

КЛЮЧЕВЫЕ СЛОВА: Polychaeta, Nephtyidae, Micronephthys, Северная Европа, Арктика. 


\section{Introduction}

Three nepthtyid genera inhabit Northern European and Arctic Seas: Aglaophamus Kinberg 1866, Nephtys Cuvier, 1817, and Micronephthys Friedrich 1939. The first includes only two easily distinguishable species, the second has been recently reviewed by Rainer (1984, $1989,1990,1991)$, and the third is here reviewed. The Micronephthys from Western Europe are poorly known, as they are irregularly present. They occur in Russian seas, but have never been reported from the North Sea and, conversely, are present in the Mediterranean. Such strange distribution may be caused by a misidentification, as small Nephtyidae (correctly identified as Micronephthys by Russian specialists (Zatsepin, 1948; Dnestrovskaja, Jirkov, 2001), might be identified as juvenile Nephtys or Aglaophamus in Western Europe.

The analysis of numerous specimens of Micronephthys from North European and Arctic seas shows that there are at least three species: M. minuta (Theel, 1879), M. neotena (Noyes, 1980), and M. hartmannschroederae Jirkov, Dnestrovskaya, 2001. Morphologically, these species can be easily identified under a stereomicroscope, both in living or preserved conditions. Also, they are easily distinguishable from the juveniles of other genera. Besides, they also have separate ecological niches, inhabiting different water masses and having different spawning times and distribution areas.

\section{Material and methods}

This study is based on material collected by Russian and Soviet expeditions and deposited at the Department of Hydrobiology of Moscow State University (DHMSU), Zoological Museum of Moscow State University (ZMUM), and Zoological Institute of Russian Academy of Science, St.-Petersburg, former Leningrad (ZIN). In addition, specimens of $M$. hartmannschroederae have been found in the collection of the Zoological Museum and Institute of the University of Hamburg (ZMH).
The sampling area covers most Arctic Ocean, from Faeroe Islands and Iceland to the Bering Strait, and from the upper shelf to abyssal depths. The Barents and White Seas are the best represented, but samples from the Norwegian and Siberian Seas are also numerous. However, as the investigated species inhabit almost exclusively shallow waters and there is no data available from the shallow Norwegian Sea, the presence of the genus cannot be assessed for this area.

Most specimens were fixed in a $4 \%$ formaldehyde seawater solution and transferred to $70 \%$ alcohol (ethanol or isopropanol), some were observed in vivo. To observe chaetae, some parapodia were dissected and mounted in glycerine jelly. Fixed worms were stained with methyl blue without a defined protocol, just to increase the contrast of some external morphological features (i.e. parapodia, prostomium, peristomium and pharynx). Drawings were made with the help of a camera lucida attached to a light microscope.

Synonymies have been limited to papers referring to the examined species, having either detailed descriptions and informative illustrations or confirmed identifications.

The following abbreviations have been used: $\mathrm{C}$ (chaetiger) and $\mathrm{BC}$ (branchiferous chaetiger), followed by a number referring to the segment along body (e.g. C-1: first chaetiger). Two kinds of dentate chaetae have been distinguished: spinose (having spines arranged in transversal rows, or combs) and serrated (having spines arranged in a single longitudinal row). Some authors (Rainer, Hutchings, 1977; Rainer, 1984, 1989, 1990, 1991; Rainer, Kaly, 1988, Hilbig, 1994, 1997) also separate spinose and spinulose chaetae, having fine and coarse spines, respectively. However, after numerous SEM observations, we conclude that this difference appears exclusively subjective and decided not to use such a distinction.

Branchiae and interramal cirri refers to the same structure and its use is exclusively matter of taste. We simply use branchiae just because it is shorter. 


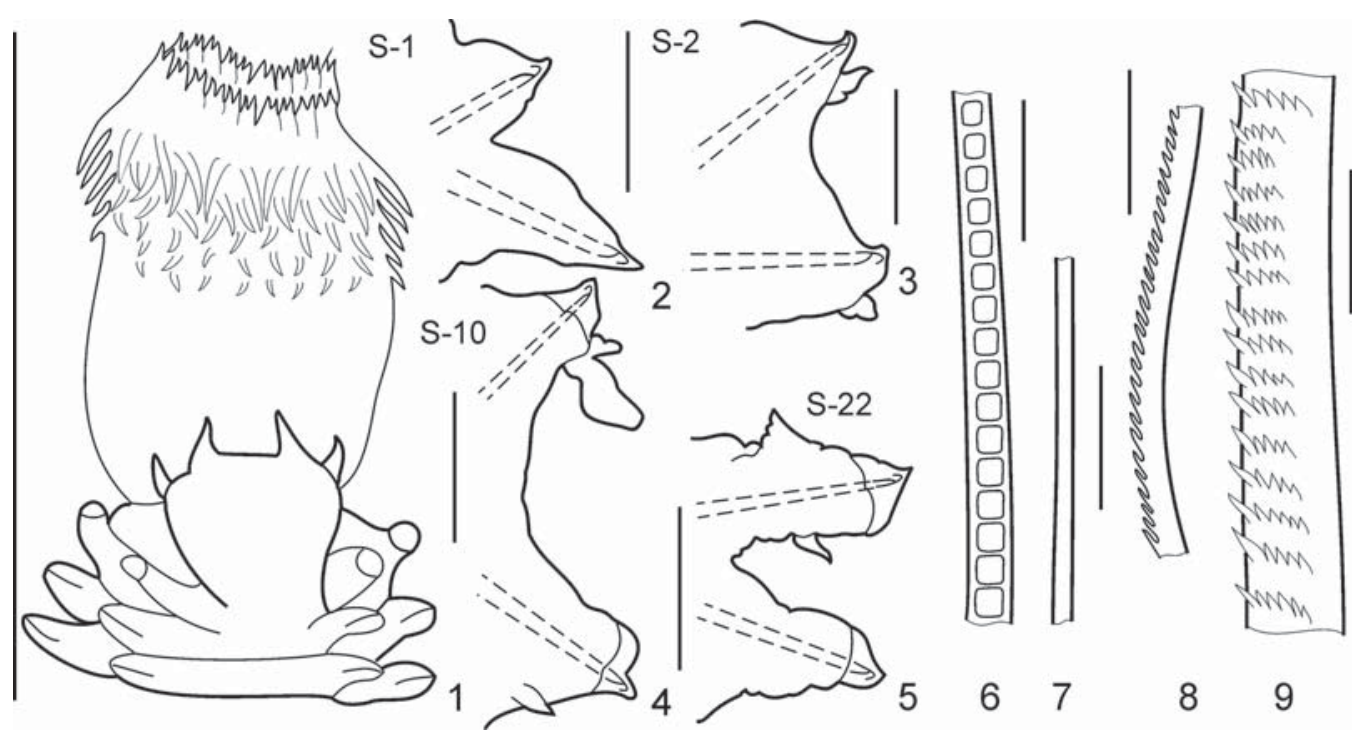

Fig. 1. Micronephthys hartmannschroederae.

1 - dorsal view of anterior end with everted pharynx; $2-5$ - parapodiae, anterior view (chaetae not shown); 2 parapodium of C-1;3 - parapodium of C-2;4 - parapodium of C-10;5 - parapodium of C-22; 6-9 - fragments of chaetae: 6 - barred chaeta; 7 - capillary chaeta; 8 - serrated chaeta; 9 - spinose chaeta. Scales: $1-1 \mathrm{~mm} ; 2-$ $5-0.1 \mathrm{~mm} ; 6-9-0.01 \mathrm{~mm}$.

Рис. 1. Micronephthys hartmannschroederae.

1 - простомиум с вывернутой глоткой и передними щетинконосными сегментами (ЩС), вид со спины; $2-5-$ параподии спереди (щетинки не изображены): 2 - параподия ЩС-1; 3 - параподия ЩС-2; 4 - параподия ЩС10; 5 - параподия ЩС-22; 6-9 - фрагменты щетинок: 6 - поперечно-исчерченная щетинка; 7 - гладкая щетинка; 8 - щетинка с латеральным рядом зубчиков; 9 - щетинка с «гребенками» из зубчиков. Масштаб: $1-1$ мм; 2-5-0,1 мм; 6-9-0,01 мм.

Micronephthys hartmannschroederae Jirkov, Dnestrovskaya, 2001

Fig. 1.

Micronephthys hartmannschroederae Dnestrovskaya, Jirkov, 2001: 190-192.

MATERIAL EXAMINED: two samples with two specimens (ZMH, P-18917 and P-18918), Kieler Bucht.

DESCRIPTION. Entire animals $3 \mathrm{~mm}$ long for 33 chaetigers. Colourless when preserved.

Prostomium with anterior half broader than posterior one with everted pharynx, straight or gently convex anterior margin, flattened dorsum, markedly convex antero-laterally. Prostomium and peristomium of group II structure(Ohwada, 1985a).

Posterior prostomial margin fused to $\mathrm{C}-1$. Antennae and palps near antero-lateral prostomial corners. Antennae conical, on anterior prostomial margin, forward directed. Palps conical, ventral, behind and below antennae on anterolateral prostomial margin, forward and sideward directed. Everted pharynx with 20 bifid, radially flattened terminal papillae, lacking simple mid-dorsal and mid-ventral terminal papillae. About 20 rows of short subterminal papillae on distal half of pharynx; subterminal papillae long, conical, decreasing in size towards proximal pharyngeal end, from 2 to 5-6 per row. First 23 papillae in each row interweaving with papillae from neighbouring rows. Mid-dorsal papilla absent. Remaining pharynx surface smooth.

C-1 notopodium with low conical acicular lobe, slightly protruding on basal part of parapodium. C-1 neuropodium c. twice longer than notopodium, acute, conical, with both rami drawing close together; C-1 cirri non-visible.

Parapodial rami well apart from each other from $\mathrm{C}-2$ to last $\mathrm{BC}$, then abranchiate and again drawing close together. Ventral and notopodial cirri starting on C-2, similar in size along body. Prechaetal and postchaetal lamellae on both 
parapodial rami rudimentary, postchaetal one slightly more distinct, especially on neuropodia. Acicular lobes conical. Acicula strong, tapering to fine curved tip, directed away from interramal space. Interramal surface and branchiae smooth. Branchiae occupying c. 1/4 of interramal space, with a central flat expansion, slightly tapering to round, flattened distal ends.

Branchiae from C-5 or C-6 to C-19, on c. $14-15$ chaetigers.

Noto- and neurochaetae deep "U" arranged around acicular lobes, with pre- and post-acicular «U» limbs directed away from the interramal space. Chaetae of four types: 1) thin serrated, with a lateral row of small spines, postacicular, nine at maximum, gradually decreasing in number towards last BC;2) spinose, 1.5-2 times thicker than serrated ones, with larger teeth joining in combs with variable teeth number at middle, all in a postacicular row near acicula, four at maximum; 3) barred, all preacicular, 6 at maximum; 4) capillary, all on ventral-most and dorsal-most position in each rami, 7 at maximum, two times thicker anteriorly. A few additional thin, small capillary chaetae on different chaetigers probably representing tips of growing.

C-1 with a preacicular row of barred notochaetae and a postacicular row of capillary notochaetae and capillary neurochaetae only. Barred neurochaetae from C-2 until posterior body end. Serrated noto- and neurochaetae from C-3 and C-4, respectively. C-4 with some serrated chaetae (near acicula) having a single row of big spines (similar to the biggest ones in spinose chaetae). Spinose noto- and neurochaetae from C-5 and C-6, respectively, gradually increasing in size and number of spines on transversal rows from $\mathrm{C}-5$ to $\mathrm{C}-7$, thus being gradually divided in spinose and serrated over 3-6 chaetigers.

REMARKS. Micronephthys hartmannschroederae differs from all known species in the presence of both spinose and serrated chaetae and a higher number of $\mathrm{BC}$, a distinguishing branchial form. As well as in lacking the subterminal median pharyngeal papilla.

DISTRIBUTION. Known only from the type locality. Probably widely distributed in the North Sea and boreal East Atlantic.
Micronephthys minuta (Theel, 1879) Friedrich, 1939

\section{Fig. 2.}

Nephthys minuta Theel 1879: 28-29, P1.2, fig. 18, type locality $72^{\circ} 53^{\prime} \mathrm{N}, 52^{\circ} 53^{\prime} \mathrm{E}, 7-17 \mathrm{~m}$; Matochkin Shar, $73^{\circ} 19^{\prime} \mathrm{N}, 7-34 \mathrm{~m}$.

Nephthys minuta - Zatsepin, 1948:122, table. XXX, 12 (partim); Gorbunov, 1946: 38; Uschakov, 1955: 217 (partim).

Micronephthys minuta - Tzetlin, 1980: 25 (partim); Jirkov, 1989:74, fig. 15.4 (partim); Jirkov, Paraketsova, 1996: 831-833, fig.1, Dnestrovskaya, Jirkov, 2001: $192-$ 193 - non Pettibone, 1963:188-190, fig. 47 b, c. 161.

?Micronephthys minuta - Averintsev, 1990: 160-

Micronephthys sp. aff. minuta - Fournier, Pocklington, 1984: 261.

MATERIAL EXAMINED. 39 samples with 264 specimens (DHMSU, 18-270 m) and five samples with 21 specimens (ZIN).

DESCRIPTION. Entire animals $14 \mathrm{~mm}$ long for 34 chaetigers, up to $16 \mathrm{~mm}$ (Theel, 1879).

Prostomium with non-everted pharynx subsquare, anterior margin slightly festooned. Antennae and palps near antero-lateral prostomial corners, forward and sideward directed, arising from a bulbous base, conical, similar in size, well apart. Palps bifid, upper branch twice as long as second, difficult to distinguish in poorly preserved or small specimens. Nuchal organs large, dorsal, just after posterior prostomial margin, often non-visible afer fixation. Peristomium nonenglarged neither flattened. Prostomium and peristomium of group II structure (Ohwada, 1985a).

Everted pharynx with 18 radially flattened terminal papillae, all bifid, with one mid-dorsal and one mid-ventral smooth gaps; subterminal papillae in 18-20 very regular rows, non-joining proximally; papillae conical, small, decreasing in size towards proximal pharyngeal end; first papilla twice bigger than second one, second twice bigger than third and so on; 4-6 per row at least (a few more small papillae may be present, but difficult to distinguish). One (hardly visible under light microscope) long unpaired mid-dorsal papilla. Remaining pharyngeal surface smooth. Rows of subterminal papillae very regular and do not join each other proximally. Drawn pharynx reaches C-10.

C-1 notopodium with low conical acicular lobe; $\mathrm{C}-1$ neuropodium truncated, conical, with 


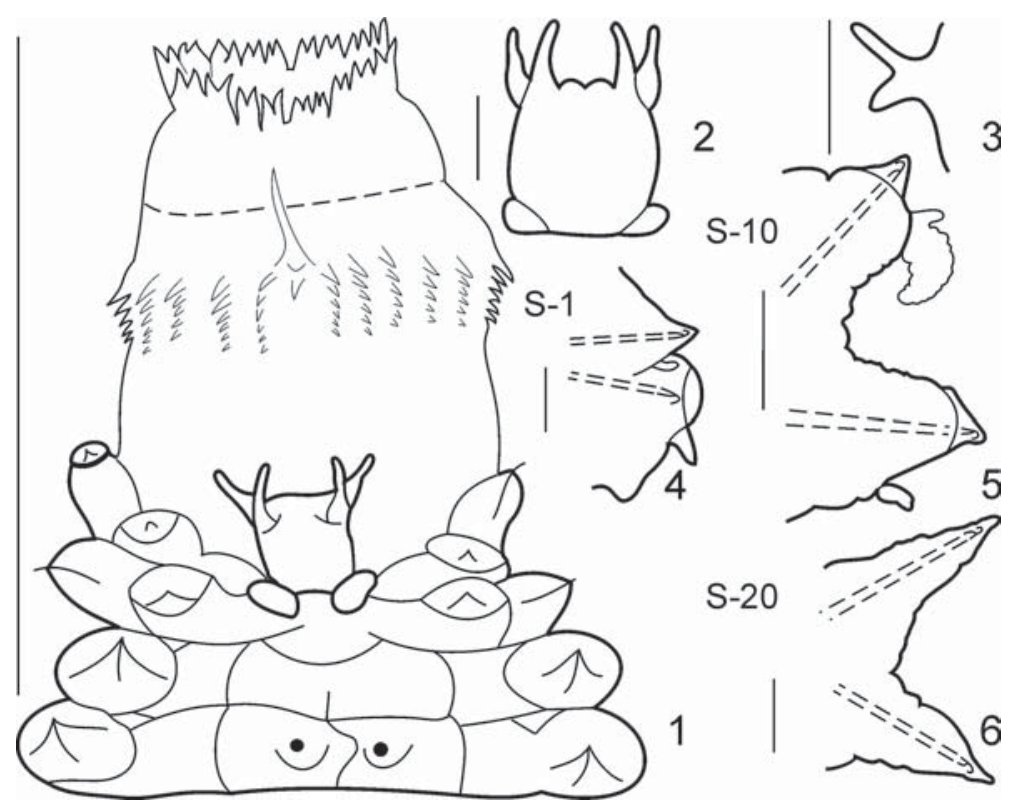

Fig. 2. Micronephthys minuta.

1 - dorsal view of anterior end with everted pharynx; 2 - prostomium with non-everted pharynx; 3 - bifid palp, lateral view; 4-6 - parapodia, anterior view (chaetae not shown): 4 - parapodium of C-1; 5 - parapodium of C-10; 6 parapodium of C-20. Scales: $1-1 \mathrm{~mm} ; 2-6-0.1 \mathrm{~mm}$.

Рис. 2. Micronephthys minuta.

1 - простомиум с вывернутой глоткой и передними ЩС, вид со спины; 2 - простомиум червя с невывернутой глоткой; 3 - двуветвистая пальпа, вид сбоку; 4-6 - параподии спереди (щетинки не изображены): 4 параподия ЩС-1; 5 - параподия ЩС-10; 6 - параподия ЩС-20. Масштаб: 1 - 1 мм 2-6 - 0,1 мм.

both rami slightly protruding from body surface, drawing close together.

Ventral and notopodial cirri starting from C-1, similar in size all along body, except for C-1 (very small, visible only after staining). From C-2, parapodia sideward directed, with prechaetal and postchaetal lamellae on both rami non distinguishable in small worms (less than 3-4 mm), even after staining. Big specimens with rudimentary lamellae and conical acicular lobes. Acicula strong, tapering to a fine curved tip with distinct transversal notches, directed away from interramal space.

Interramal surface and branchiae wrinkled. Branchiae occupying c. 1/3 of interramal space, straight or slightly involutes on some more developed chaetigers, tapering distally.

Branchiae on 5-9 chaetigers, from C-6-C-8 to $\mathrm{C}-10-\mathrm{C}-14$, in worms longer than $3 \mathrm{~mm}$.

Total number of chaetigers significantly and positively correlated to order of last BC (Pear- son's coefficient $=0.691, \mathrm{p}<0,001)$ and total number of BC ( Pearson's coefficient $=0.607, \mathrm{p}<$ 0.001 ).

Noto- and neurochaetae deep " $U$ " arranged around each acicular lobe, with pre- and postacicular «U» limbs directed away from interramal space. Chaetae of three types, with long and short chaetae each (short ones more rare than long ones, probably being tips of growing chaetae). Barred chaetae all preacicular, starting on notopodium C-1 and on neuropodium C-2, being replaced by smooth chaetae $2-3$ chaetigers after last BC, 3-11 at maximum, short ones very rare, absent from most chaetigers and some worms. Serrated chaetae postacicular, starting few chaetigers before branchiae, 10 at maximum, short ones extremely rare. Capillary chaetae starting on $\mathrm{C}-1$, always postacicular. About 10-20 long capillary and long serrated chaetae together in anterior and mid-body chaetigers, difficult to distinguish under light microscope. 
On well developed branchial chaetigers, capillary chaetae generally occurring in interramal space), with 3-5 inserted close together, forming a compact fascicle and a few ones separated, inserted on other postacicular regions. About 10 serrated chaetae per BC, generally outer to acicula, without distinct compact fascicles, with 1-3 being of short type on all chaetigers. The more size of worms the more number of chaetae. C-1 notopodia with preacicular row of barred chaetae and postacicular row of capillary chaetae only; C-1neuropodium with capillary chaetae only. Barred chaetae starting on C-2.

Preserved worms colourless. Living worms with two black dorsal spots in lower part of brown loop (i.e. brain) between C-3 and C-4, over pharynx but visible by transparency. Blood vessels ending between these spots, running dorso-medially to pigidium, with some loops near proximal part of everted pharynx, connecting also to branchiae. A wide darkish-green stripe with two lateral blood vessels running ventrally. Prostomium greenish, body pale-rose, with a belt of little reddish-brown spots at midpygidium, tending to disappear in preserved material depending on preservative, fixative, keeping conditions, etc.

Pigidium with long ventral cirrus.

REMARKS. Despite Micronephthys minuta was described from the Barents Sea, there were only four specimens from the open Sea in investigated material $\left(69^{\circ} 55^{\prime} \mathrm{N}, 42^{\circ} 00^{\prime} \mathrm{E}, 125\right.$ $\mathrm{m} ; 72^{\circ} 36^{\prime} \mathrm{N}, 50^{\circ} 41^{\prime} \mathrm{E}, 162 \mathrm{~m}$, and $74^{\circ} 30^{\prime} \mathrm{N}$, $50^{\circ} 23^{\prime} \mathrm{E}, 136-138 \mathrm{~m}$ ) and having branchiae from C-7 to C-13.

Micronephthys sp. aff. minuta sensu Fournier \& Pocklington (1984), agrees well with our present description, while $M$. minuta sensu Pettibone (1963) differs in having branchiae from C-12 to C-14, distinctly more posterior that in the present description. Assuming that these material belongs to Micronephthys, these specimens probably belong to another species.

DISTRIBUTION. Arctic species: the Barents Sea, the White Sea, Northern Svalbard, Canada, Nova Scotia (Fournier, Pocklington, 1984).
Micronephthys neotena (Noyes, 1980)

Fig. 3.

Aglaophamus neotenus Noyes, 1980: 106-116, fig. 1-3. Type locality: Maine and Canada (St.-John Estuary). Aglaophamus neotenus - Grenon, 1981: 111-112. Nephthys minuta - Zatsepin, 1948: 122, tabl. XXX, 12 (partim); Uschakov, 1955: 217 (partim) - non Theel, 1879.

Micronephthys minuta - Tzetlin, 1980: 25 (partim); Jirkov, 1989: 74, fig. 15.4 (partim).

Micronephthys neotenus — Jirkov, Paraketsova, 1996: 833-835, fig.2.

Micronephthys neotena - Dnestrovskaya, Jirkov, 2001: 193-194.

non Nephtys cornuta - Hilbig, 1994: 348-351, fig. 13.8; 1997: 336-338, fig. 13.8.

MATERIAL EXAMINED. 16 samples with $296 \mathrm{spec}-$ imens (DHMSU and ZMMSU); White Sea and the Barents Sea; 3-318 m.

DESCRIPTION. Entire animals $11 \mathrm{~mm}$ long (but up to $13 \mathrm{~mm}$ according to Chivilev, 1983) for 33 chaetigers.

Prostomium slightly elongated, rectangular with non-everted pharynx; anterior margin slightly festoned, distinctly convex antero-laterally. Antennae and palps near antero-lateral prostomial corners, conical, with bulbous base, all equal in size. Antennae on anterior prostomial margin, forward directed. Palps ventral, behind and below antennae on antero-lateral prostomial margin, forward and laterally directed, bifid in well-preserved large specimens (non-distinguishable in poorly preserved or small specimens), with one branch twice as long as other.

Nuchal organs large, dorsal, just on posterior prostomial end, sometimes non-visible after fixation. Peristomium not enlarged, neither flattened. Prostomium and peristomium of group II structure (Ohwada, 1985a).

Everted pharynx with 18 radially flattened, bifid, terminal papillae; with a mid-dorsal and a mid-ventral gap. Subterminal papillae conical, in proximal pharynx decreasing, with short rows of up to 6 papillae at maximum, irregular, some very short, with 1-2 papillae only, some joining proximally, or simply disappearing, so initial 20 rows reduced to 14-16. One long unpaired median dorsal papilla. Surface of pharynx otherwise smooth.

Drawn pharynx reaches C-10. 


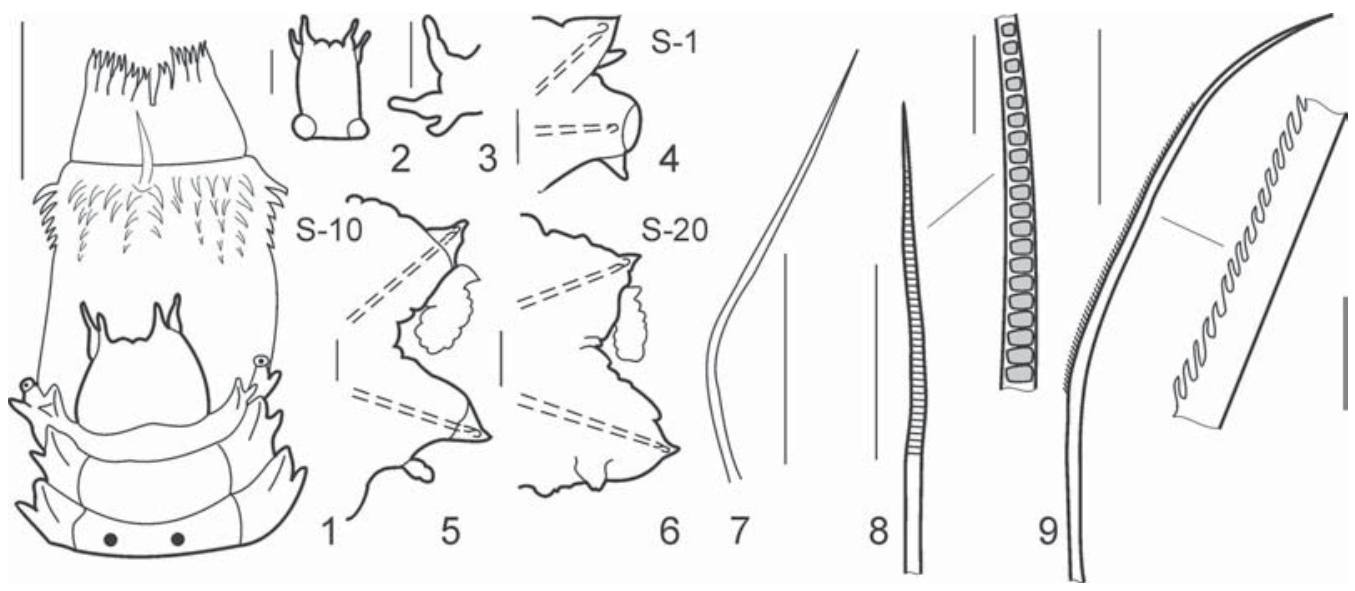

Fig. 3. Micronephthys neotena.

1 - dorsal view of anterior end with everted pharynx; 2 - prostomium with non-everted pharynx; 3 - left antenna and bifid palp, lateral view; 4-6 - parapodia, anterior view (chaetae not shown): 4 - parapodium of C-1; 5 - parapodium of C-10; 6 - parapodium of C-20; 7-9 - chaetae: 7 - capillary chaeta; 8 - barred chaeta and its enlarged part; 9 serrated chaeta and its enlarged part. Scales: $1-1 \mathrm{~mm}$; the chaetae $-0.1 \mathrm{~mm}$; enlarged parts of chaetae $-0.01 \mathrm{~mm}$. Рис. 3. Micronephthys neotena.

1 - простомиум с вывернутой глоткой и передними ЩС; 2 - простомиум червя с невывернутой глоткой ; 3 антенна и двуветвистая пальпа, вид сбоку; 4-6 — параподии спереди (щетинки не изображены): 4 — параподия ЩС-1; 5 - параподия ЩС-10; 6 - параподия ЩС-20; 7-9 щетинки: 7 - гладкая щетинка; 8 - поперечноисчерченная щетинка и ее увеличенный фрагмент; 9 - щетинка с латеральным рядом шипиков и ее увеличенный фрагмент. Масштаб: $1-1$ мм; щетинки - 0,1 мм, их увеличенные фрагменты -0,01 mm.

C-1 notopodium with low conical acicular lobe; $\mathrm{C}-1$ neuropodium truncated, conical, with both rami slightly protruding out the parapodial base. Other parapodia directed sideward.

Ventral and notopodial cirri always present, from $\mathrm{C}-1$, with little variations in size along body except C-1 (very small, visible after staining only).

Prechaetal and postchaetal lamellae on both parapodial rami, rudimentary. Acicular lobes conical. Acicula strong, tapering to fine curved tips with distinct transversal notches, directed away from interramal space.

Interramal surface and branchiae wrinkled. Branchiae occupying c. $1 / 2$ to $1 / 3$ of interramal space, straight or slightly involute, and broadly rounded distally, from C-5-C-7 to C-12-C-18, on c. 8-14 chaetigers on worms longer than 3 $\mathrm{mm}$.

Position of posterior BC in White Sea specimens slightly but significantly and positively correlated with total number of chaetigers (Pearson's coefficient $=0.402, \mathrm{p}<0.001$ ).
Chaetae of noto- and neuropodia deep " $U$ " arranged around each acicular lobe, with preand post-acicular "U" limbs directed away from interramal space. Chaetae of three types, each short and long, short ones less frequent, possibly being tips of growing chaetae. Barred chaetae all preacicular, long ones from C-1 notopodia and C-2 neuropodia, replaced by smooth chaetae 2-3 chaetigers after last branchial one, 10 at maximum. Short, barred chaetae only preacicular, absent from most chaetigers and some worms.

Serrated chaetae all postacicular, starting from few chaetigers before branchiae, 13 at maximum; short ones seen only once. Capillary chaetae from C-1 near and further from interramal region. below and above acicula. Long ones being 8 at maximum in anterior-most $1 / 4$ region, being replaced by serrated chaetae together with branchial development, practically absent on well-developed branchial chaetigers (1-2 at maximum). Short capillary chaetae c. 1-3 in all chaetigers, probably being tips of growing cha- 
etae (either capillary or serrated). Chaetae more numerous in larger worms, becoming 1.5 times longer during spawning.

C-1 with a notopodial preacicular row of barred chaetae and postacicular row of capillary chaetae only; neuropodium with capillary chaetae only. C-2 with neuropodial barred chaetae too.

Living worms with a pair of black dorsal spots at C-3, between or anterior to parapodia (disappearing in alcohol); pygidium with median belt of reddish-brow small spots. Preserved specimens colourless. Pygidium with long ventral anal cirrus.

REMARKS. The original description mentioned 14-16 rows of subterminal papillae (Noyes, 1980), while a posterior examination of the paratypes (as A. neotenus, NM 47166, Wentworth Point, Damariscotta River, Maine, USA) revealed 20-22 rows (Ohwada, 1985a), with the lower range agreeing with our observations. $M$. neotena was synonymized to Nephtys cornuta by Hilbig (1994), a very similar species likely belonging to Micronephthys, too. However, N. cornuta clearly differs from $M$. neotena sensu stricto and our specimens in having «prostomium rounded, slightly longer than wide when proboscis retracted and much wider than long when proboscis fully everted» (Hilbig, 1994: 350). Versus $M$. neotena has prostomium at least equally wide and long even if proboscis fully everted. Also, $N$. cornuta has barred chaetae «at least through chaetiger 10 to 19 » (p. 350) versus barred chaetae on all anterior chaetigers in M. neotena; «both interramal cirri and upper neuropodial wall heavily ciliated» versus ciliation absent and «straight or slightly curved branchiae» versus straight or slightly involute branchiae. Further, branchiae occupy most interamal space in $N$. cornuta, while they never occupy more than half in $N$. neotena and branchial and interramal surfaces are represented as smooth in N. cornu$t a$, while they are wrinkled in $N$. neotena.

In addition to distinguish between both species, we postulate that $N$. cornuta must be considered as a valid species, belonging to Micronephthys.

Nephtys cornuta was reported as having 18 bifid terminal papillae with an unpaired medial one and 22 rows of subdistal papillae by Banse (1972). With a high probability, this report corresponds to another species.

DISTRIBUTION. North boreal species. Main, the White Sea, Kola and other fjords of Kola Peninsula.

\section{Discussion}

\section{Remarks on Nephtyidae taxonomy}

The following characters have been recently used for the generic diagnoses among Nephtyidae:

1. Two additional rows of teeth: present (Dentinephtys) - absent (all other genera).

2. Terminal and subterminal papillae: absent (Inermonephthys) - present (all other genera).

3. Number of antennae and palps: two (Inermonephthys) - four (all other genera).

4. Branchial form: involute (Aglaophamus, Inermonephthys) - curved (Nephtys, Dentinephtys) - reduced (Micronephthys).

5. Acicular tip: hooked (Aglaophamus, Inermonephthys, Micronephthys) - usually blunt, in some species curved (Nephtys); not described in Dentinephtys.

6. Lyrate (Rainer, Hutchings, 1977; Rainer, Kaly, 1988; Hilbig 1994, 1997; Martin et al., 2009) or lyriform (Mackie, 2000) chaetae: present, of two types in some species (Inermonephthys), usually present (Aglaophamus), absent or present (Micronephthys), absent (Nephtys, Dentinephtys). Only species of Nephtys, $N$. oligobranchia Southern, 1921, has been described with lyrate chaetae and we suppose it may belong to Micronephthys.

However, the taxonomic value of these characters is different: the first three are the most robust, as they are invariable, especially to distinguish Inermonephthys from Dentinephtys. In the remaining genera (i.e. Aglaophamus, Nephtys and Micronephthys) these characters coincides, so the last three must be used, despite they might less helpful.

The branchial form distinguishes Aglaophamus from Nephtys, but not Micronephthys from Nephtys juveniles. 
Acicular tips seem not to be good as a diagnostic character. In $N$. caeca the acicula are curved in juveniles and become blunt in adults (Ohwada, 1985a, b). Adults of $N$. hystricis and $N$. incisa have always curved acicula (Rainer, 1990), while those of $N$. paradoxa have curved acicula in recently formed segments only (Dnestrovskaja, Jirkov, 2001).

The absence of lyrate chaetae does not allow to distinguish Nephtys from Aglaophamus and Micronephthys, which also lack them in some species. Moreover, the absence of a structure cannot be considered a good base for a generic diagnosis, as such a feature can have developed independently several times, so the character could be only supplementary.

Therefore, Aglaophamus and Nephtys are only distinguished by the direction of branchiae, as they share the first three characters and the last two are not strictly diagnostic. In turn, the branchial form in Micronephthys is intermediate, and the absence of branchiae cannot be considered a diagnostic character for this genus, as some species may have specimens lacking branchiae as well (e.g. Aglaophamus malmgre$n i$ in Dnestrovskaya, Jirkov, 2001). Consequently, there is a remarkable absence of diagnostic characters for Micronephthys and, particularly, characters 4 and 5 might be difficult to use in such small worms). To some extent, the genus can be considered as intermediate between $\mathrm{Ag}$ laophamus and Nephtys, this clearly pointing on the necessity of a major revision for this trigeneric complex. In other words, the whole family requires revision, as Inermonephthys and Dentinephtys together include only a $5 \%$ of the known species.

However, Micronephthys still appears as a valid genus as both their adults and (likely) their juveniles may be quite easily separated from those of the other two genera. Moreover, Micronephthys is not only characterized by a reduction in branchial size, but also by its reduced number of segments. According to our observations, juvenile Aglaophamus and Nephtys specimens have much more (i.e. twice or even more) segments than Micronephthys of the same size.
The presence of bifid palps could likely be a diagnostic character for Micronephthys, this statement needs to be confirmed with more data, as it may be easily overlooked. Moreover, bifid palps seems to be clearly developed only in adults, ocurring only in some specimens of a given population (Lovell, pers. comm.). Finally, badly preserved worms may lost the lower branch of bifid palps. Moreover recently bifid palps was found in Inermonephthys (Martin et al., 2009). In conclusion, Micronephthys includes small Nephtyidae with few segments and with reduced branchiae (or without them). The genus includes twelve species and one subspecies, five of them previously described as $\mathrm{Ag}$ laophamus or Nephtys and newly transferred to Micronephthys herein:

Micronephthys Friedrich, 1939

Type species: Nephthys minuta Theel, 1879 by original designation.

M. abranchiata (Ehlers, 1913) as Nephthys.

M. ambrizettana (Augener, 1918) as Nephthys.

M. cornuta (Berkeley, Berkeley, 1945) comb.n. as Nephthys (redescription of types - as Nephtys Hilbig, 1994; Lovell, 1997).

M. danida (Nateewathana, Hylleberg, 1986) comb.n. as Nephtys.

M. hartamannschroederae Jirkov, Dnestrovskaya 2001.

M. maryae San Martin, 1982, synonym of $M$. stammeri according to Ravara et al. (2010).

M. minusculus (Hartman, 1965) comb.n. as $A g$ laophamus (redescription of types - Ohwada, 1985b).

M. minuta (Theel, 1879) as Nephthys minuta.

M. neotena (Noyes, 1980) Jirkov, Paraketsova, 1996, as Aglaophamus.

M. oculifera Mackie, 2000.

M. oligobranchia (Southern, 1921) comb.n. as Nephthys.

M. sphaerocirrata (Wesenberg-Lund, 1949) as Nephthys.

M. sphaerocirrata orientalis Lee, Jae, 1983.

M. stammeri (Augener, 1932) as Nephthys.

Most of our material studied belong to $M$. minuta sensu stricto and $M$. neotena, whith only two specimens of $M$. hartmannschroederae being available, so that the character variability refers to the first two species. However, as the respective trends were the same, we expect just the same variability for M. hartmannschroeder$a e$ and for other species as well. 


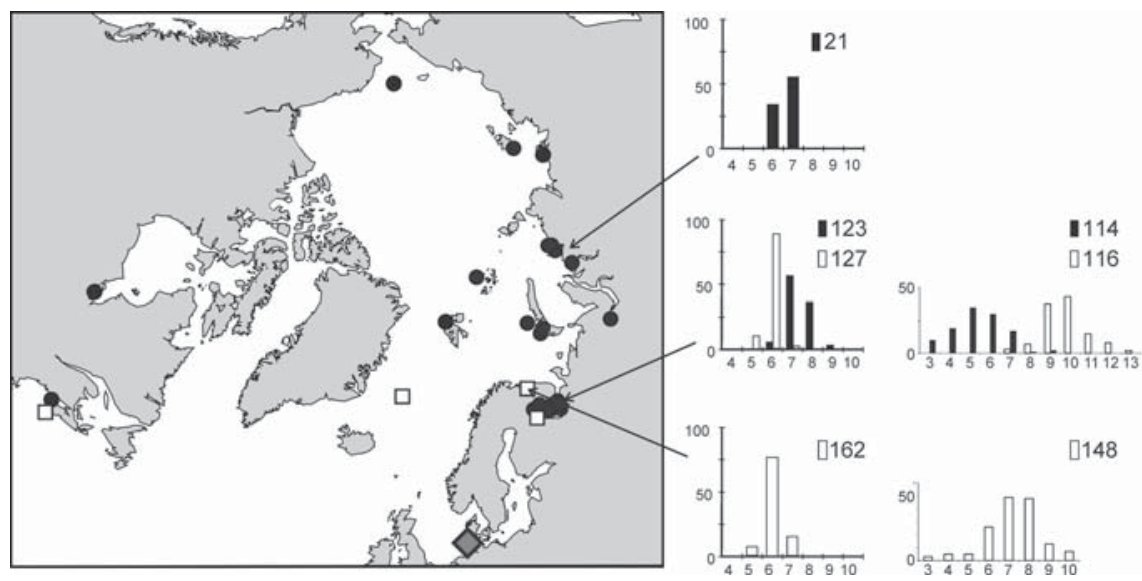

Fig. 4. Species ranges of Miconephthys spp.

Black circle - M. minuta, empty square $-M$. neotena; rombus - M. hartmannschroderae. Columns charts show percent of specimens with different order of $\mathrm{BC}$ in the referred localities, numbers - number of investigated specimens. Left — order of BC-1, right — number of BC.

Рис. 4. Ареалы Miconephthys spp.

Черные кружки- M. minuta, квадраты - M. neotena; ромб - M. hartmannschroderae. На диаграммах показан процент червей с различным числом сегментов с жабрами в указанных районах. Числа - число изученных червей. Левые графики - номер первого сегмента с жабрами, правые - общее число сегментов с жабрами.

Some investigated worms were complete, it allows as to investigate relationships between size and come meristic characters. The relationship between total number of $\mathrm{BC}$ and total number of chaetigers $(C)$ revealed to be speciesspecific, with the coefficients in the linear regression equation (i.e. "a" and "b" i Total $\mathrm{BC}=$ $\mathrm{a}+\mathrm{bC}$ ) statistically differing between $M$. minuta sensu stricto $(\mathrm{a}=-5.3 \pm 2.4, \mathrm{~b}=0.42 \pm 0.09)$ and $M$. neotena $(\mathrm{a}=3.1 \pm 1.9, \mathrm{~b}=0.22 \pm 0.06)$. This difference is still more marked in small worms with few BC.

The relationship between order of last $\mathrm{BC}$ and $\mathrm{C}$ is also species-specific with the coefficients in the equation "last $\mathrm{BC}=\mathrm{a}+\mathrm{bC}$ " statistically differing between $M$. minuta $(\mathrm{a}=$ $3.6 \pm 1.5, \mathrm{~b}=0.31 \pm 0.06)$ and $M$. neoten $a(\mathrm{a}=$ $8.5 \pm 1.8, b=0.21 \pm 0.06)$, and the difference in order of last $\mathrm{BC}$ being more marked in worms with lower total C (Jirkov, Paraketsova, 1996).

Comparison of the regressions shows that total number of $\mathrm{BC}$ is more valuable diagnostic feature, since the difference between the two species in this feature is significant in wider range of segments' amount (Fig. 4).
The pharynx is also highly characteristic, particularly when using methyl blue staining to highlight the main features in such a small-sized species. M. hartmannschroederae lacks the median dorsal subterminal papilla, which is present in M. minuta and M. neotena.

The prostomial shape may only be used as an additional specific character when the pharynx is not protruding, as it is almost square in $M$. minuta and slightly elongated and rectangular in M. neotena.

The differences between the three species described above and the remaining ones are, thus, obvious (Table 1), but it must be taken into account that all main morphometric characters (order of BC-1, order of last BC and number of BC) show a geographical variability. Micronephthys minuta and $M$. neotena differ obviously in the White Sea, where both species cooccur, but this difference become less evident in regions inhabited by only one species (see Fig. 4). Despite the range of variability in the number of BC-1 overlap for all three species, this character seems to be useful for a preliminary identification. It is easily visible under a stereomi- 
Micronephthys (Polychaeta: Nephtyidae) of Northern Europe and Arctic
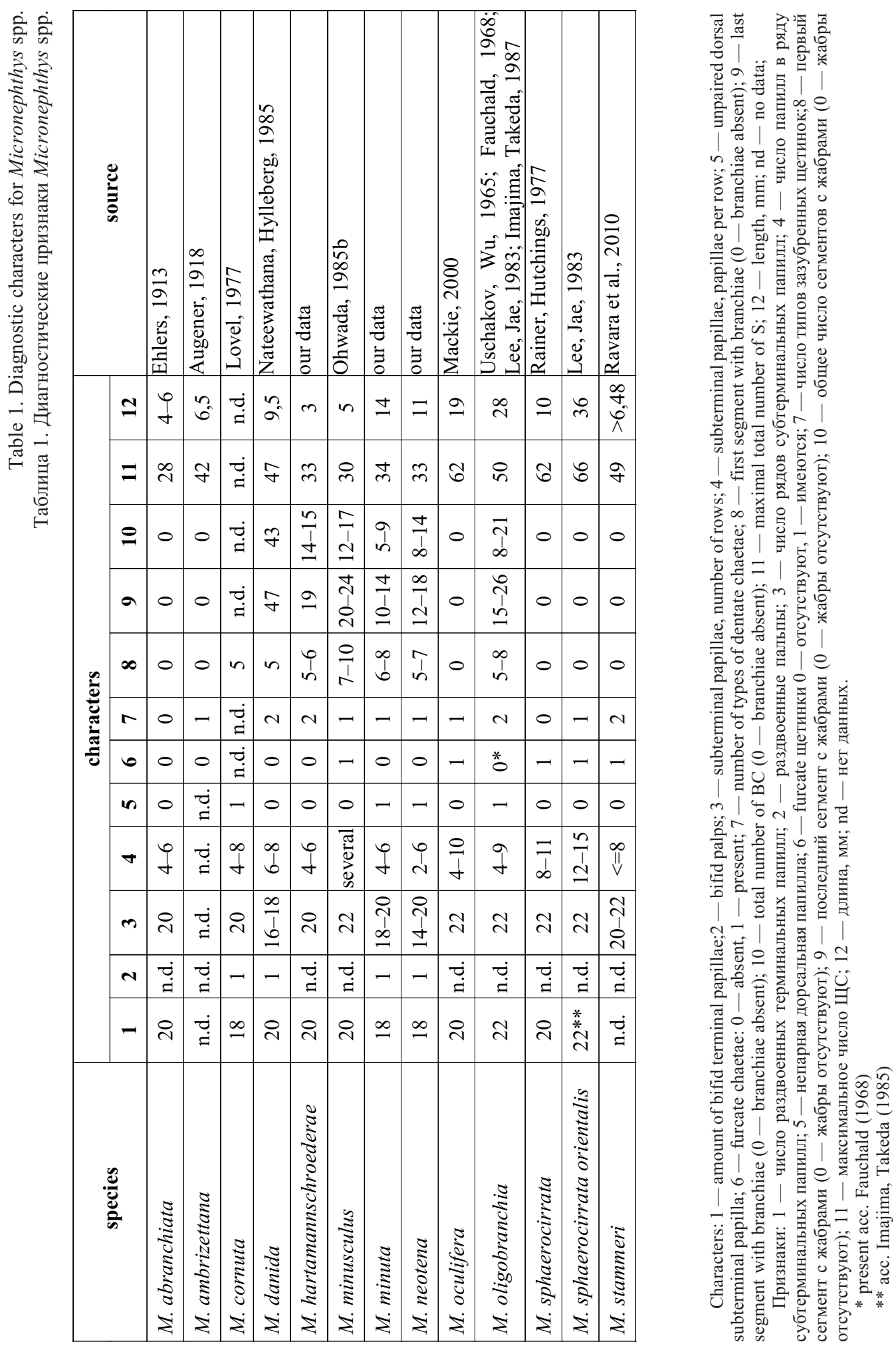
croscope (no slides are required) so that it may always be used in vivo, without physically damaging the worms. Nevertheless, the use of this character requires analyzing populations, being thus doubtful for single specimens. In our case, we obtained sufficient representatives from some marginal biotopes (see below). Any first approach to the species inhabiting a given area would require the study of enough specimens allowing significant statistical analyses, together with some specimens with everted pharynx to be better observed after staining (to increase the contrast).

\section{Comparative biology of European $\mathrm{Mi}$ - cronephthys species}

As for the morphological comparisons, most information on the biology of Micronephthys concerns to $M$. minuta sensu stricto and $M$. neotena, as the single finding of $M$. hartmannschroederae only allowed us to speculate.

Micronephthys spp. (as M. minuta) in the White Sea, mainly inhabits the upper (2.5-4 $\mathrm{cm})$ layer of silty intertidal and shallow water organically rich sediments, actively moving with at up to $20 \mathrm{~cm} / \mathrm{sec}$ (Lvova, 1981). In aquarium, it has been seen swimming.

The species tolerates large salinity fluctuations in experimental conditions: from 15 to $35 \%$ in White Sea gametes and larvae, extending from 10 to $40 \%$ in adults (Lvova, 1981), which agree with our field data.

Micronephthys minuta can be characterized as an Arctic species, while M. neotena and M. hartmannschroederae appeared to be northand south-boreal, respectively (Fig. 4). Despite the species ranges seems to overlap, the respective populations never co-exists. In such places Micronephthys minuta occurs deeper below thermocline in more cold water then $M$. neote$n a$. In such places morphological difference between species increase. At the same time species-specific ecological requirements at least M. minuta and M. neotena is very similar. So we assume that such distribution more likely due to large-scale biogeographical constraints (Arctic and north boreal distributions) or belonging to different biomes (Acrtic and boreal ones).

Spawning of Micronephthys spp. occurs in late May - early June in the White Sea, when the temperature ranges between 4 and $8^{\circ} \mathrm{C}$ (Lvova, 1976, 1978, 1981; Chivilev, 1981, 1982, 1983), and from late March to early May near the State of Man, much warmer (Noyes, 1980). Each female produces from $250-400(6 \mathrm{~mm}$ long specimens) to up to $9000-10000(12-13 \mathrm{~mm}$ long specimens) oocytes (Lvova, 1981), measuring about $95 \mu \mathrm{m}$ in diameter (Chivilev, 1981). The pelagic development near Man (USA) finishes in June (Noyes, 1980). In the White Sea, at $5 \mathrm{~m}$ deep, two settlement peaks were identified: at mid-summer and autumn, with approximately the same abundances (Chivilev, 1981). Peaks were not observed in March 4, but were already present on June 21, September 15 and October 10. However, according the local oogenesis period, spawning takes place only once, before the summer peak (Chivilev, 1981). Thus, the origin of the autumn peak was unclear. Tentatively, we may hypothesize that it corresponds to M. minuta sensu stricto. However, the situation was not so simple. In 1991, we observed intracoelomic oocytes on July 27 in a102 m deep population, while they were absent from a neighbouring $18 \mathrm{~m}$ deep population on July 24 . Consequently, M. minuta seems to spawn during different periods depending on depth (i.e. water mass and temperature): together with $M$. neotena in the intermediate water mass, and later in deeper waters, this last likely being the source of the observed autumn peak of Micronephthys spp. settlement. Uschakov, Wu (1965) mentioned two spawning period for M. oligobranchia as well.

Therefore, the combined influence of both depth and bottom temperature seems not to be a limiting factor (at least on the shelf) for the development of $M$. minuta and $M$. neotena populations. The study at Kola Fjord strongly supports the relevance of the inter-specific competition. In the other words, $M$. neotena may inhabit the same habitat as M. minuta (e.g. the deep Kola Fjord bottoms). However, the latter appear to suppress the presence of the former 
Table 2. Abiotic conditions for the findings of Micronephthys spp.

Таблица 2. Данные по абиотическим условиям в местах находок Micronephthys spp.

\begin{tabular}{|c|c|c|c|c|}
\hline & depth (m) & $\max \mathbf{T}\left({ }^{\circ} \mathrm{C}\right)$ & salinity (\%o) & Source \\
\hline \multicolumn{5}{|c|}{ M. minuta } \\
\hline White Sea, below thermocline & $18-270$ & $3-4$ & 30 & our data \\
\hline Open Barents Sea & $25-162$ & 2.5 & normal & our data \\
\hline Lena estuary, above thermocline & $3-15$ & 2 & $>15$ & Averintsev, 1990 \\
\hline $\begin{array}{l}\text { Nova Scotia, Canada, below } \\
\text { thermocline }\end{array}$ & $9-195$ & $<6$ & $21-26$ & $\begin{array}{c}\text { Fournier \& } \\
\text { Pocklington, } 1984 \\
\end{array}$ \\
\hline \multicolumn{5}{|c|}{ M. neotena } \\
\hline White Sea, above thermocline & $3-10$ & 18 & 25 & our data \\
\hline Kola Fjord, above thermocline & $>8$ & 14 & $? 34.5$ & our data \\
\hline Kola Fjord, below thermocline & to 318 & 4.5 & 34.5 & our data \\
\hline $\begin{array}{l}\text { Quebec } 52^{\circ} 15^{\prime} \mathrm{N} 78^{\circ} 35^{\prime} \mathrm{W} \text {, above } \\
\text { thermocline }\end{array}$ & $2-8$ & 13 & $12-21$ & Grenon, 1981 \\
\hline Main, above thermocline & $0-10$ & 17 & $19-30$ & Noyers, 1980 \\
\hline
\end{tabular}

(as in the deep White Sea). Vice versa, both species may settle in the same place (e.g. the upper White Sea), but only one recruitment (i.e. that of M. neotena) develops further. A similar inter-specific competition seemed to explain the alternancy in population densities for the scale-worms Lepidonotus squamatus and Harmothoe imbricata, which also coexist in the White Sea (Plyuscheva et al., 2004).

In summary, we suggest that the two of Micronephthys species behave as r-strategists, being widely distributed but rare, not only because they are small (and, thus, easily lost or overlooked during sample handling) or may be easily misidentified (as Nephtys juveniles), but because their densities are quite often very low. In contrast, they may be abundant (as much as 8000 ind. $\mathrm{m}^{-2}$ (Lvova, 1981; Chivilev, 1981) in marginal biotopes, where the overall species diversity is low (e.g. the White Sea, estuaries etc.). As mentioned above, we may only assume the a similar situation could be expected for $M$. hartmannschroederae.

\section{Final remark}

After finishing paper we have got possibility to read paper Ravara et al. (2010), where authors describe new genus Bipalponephtys. All characters which authors propose to be diagnos- tic for their new genus absolutely the same which are characteristic for type species of Micronephthys - M. minuta, so Bipalponephtys is no more then junior synonym of Micronephthys. Ascensao Ravara when the problem have been discussed at 10th International Polychaete conference agreed with our opinion.

\section{Acknowledgements}

We would like to express our gratitude to G. Buzhinskaya, V. Potin (ZIN) for allowing us to study their collections. We are indebted to Dr. Alexander B. Tzetlin (Department of Invertebrate Zoology of Moscow State University) and Andrew V. Sikorsky (ZMUM) for loan of material, and to Dr. G. Hartmann-Schroeder for her hospitality during a visit to the Zoological Museum and Institut of Hamburg University. We also thank Dr. M. Petersen for a fruitful discussion on genus-level taxonomy, and to Prof. A. Azovsky (DHMSU) for the discussions on statistics. To anonymous referee for correcting English.

To work with the collections of the Zoological Museum and Institut of Hamburg University has been possible due the financial support of DAAD (Deutscher Akademischer Austauschdienst). 


\section{References}

Averintsev V.G. 1990. [The polychaetous fauna of the Laptev Sea] // Issledovaniya fauny morei. No.37(45). P.147-209 [in Russian].

Augener H.1918. Polychaeta // Beitrage zur Kenntnis der Meeresfauna Westafrikas. Bd.2. No.2. S.67-625.

Banse K. 1972. On some species of Phyllodocidae, Syllidae, Nephtyidae, Goniadidae, Apistobranchidae, and Spionidae (Polychaeta) from the Northeast Pacific // Pacific Science. Vol.26. No.2. P.191-222.

Chivilev S.M. 1981. [Oogenesis and reproduction of $\mathrm{Mi}$ cronephthys minuta (Theel) (Polychaeta: Nephyidae) in the White Sea] // Vestnik Leningradskogo Univ. Vol.9. P.113-115 [in Russian].

Chivilev S.M. 1982. [Peculiarities characteristics, features; habits, peculiarities, traits of growth White Sea Polychaeta] // Vestnik Leningradskogo Univ. Vol.15. P.15-20 [in Russian].

Chivilev S.M. 1983. [Ecology of common upper-shelf, soft bottom Polychaeta species of Chupa Bay, the White Sea]. Autoreferate of Ph. D thesis. Leningrad Univ. 23 p. [in Russian].

Dnestrovskaya N.Yu., Jirkov I.A. 2001. [Nephtyidae Grube, 1850] // I.A. Jirkov. Polychaeta of the Arctic Ocean. Moscow: Yanus-K. P.181-212 [in Russian].

Ehlers E. 1913. Die Polychaeten-Sammlungen der deutche Sudpolar-Expedition 1901-1903 // Deutsche Sudpolar-Expedition Vol.13 (Zoologishe Heft 4). S.397598, P1. 26-46.

Friedrich H. 1939. Polychaeten-Studien IV. Zur Polychaetenfauna der Barents-See // Kieler Meeresforschungen. Vol.3. No.1. S.122-132.

Fournier J.A., Pocklington P. 1984. The sublittoral polychaete fauna of the Bras d'Or lakes, Nova Scotia, Canada // 1st Intern. Polych. conf. Publ. Lin. Soc. NSW. Vol.2. P.278.

Fauchald K. 1968. Nephtyidae (Polychaeta) from the Bay of Nha Trang, South Viet Nam // Naga Report. Vol.4. P.1-33.

Gorbunov G.P. 1946. [Bottom life of the Novosiberian shoalwaters and the central part of the Arctic Ocean] // Trudy dreifuyushchei ekspeditsii Glavsevmorputi na ledokol'nom parokhode «G.Sedov» 1937-1940. Moscow-Leinigrad: Glavsevmorput Press. Vol.3. P.30-138 [in Russian].

Grenon J.-F. 1981. First record of Aglaophamus neotenus (Polychaeta: Nephtyidae) for Quebec and Arctic regions // Natutaliste can. Vol.108. P.111-112.

Hartman O. 1950. Goniadidae, Glyceridae, and Nephtyidae // Allan Hancock Pacific Exped. Vol.15. No.1. 181 p.

Hartman O. 1965. Deep-water benthic polychaetous annelids off New England to Bermuda and other North Atlantic areas // Allan Hancock Found. Occ. Paper. Vol.28. $378 \mathrm{p}$.

Hilbig B. 1994. 13. Family Nephtyidae Grube, $1850 / /$ J.A. Blake, B. Hilbig (eds.). Taxonomic atlas of the benthic fauna of the Santa Maria Basin and Western Santa Barbara Channel. Vol.4. Santa Barbara, Cali- fornia: Santa Barbara Museum of Natural History. P. 329-362.

Hilbig B. 1997. 13. Family Nephtyidae Grube, 1850 // J.A. Blake, B. Hilbig (eds.). Taxonomic atlas of the benthic fauna of the Santa Maria Basin and Western Santa Barbara Channel. Vol.4. Santa Barbara, California: Santa Barbara Museum of Natural History. P. 317-347.

Imajima M., Takeda Y. 1985. Nephtyidae (Polychaeta) from Japan. 1. The genera Inermonephthys, Micronephthys, and Aglaophamus // Bull. Natn. Sci. Mus., Tokyo, Ser. A. Vol.11. No.2. P.57-90.

Imajima M., Takeda Y. 1987. Nephtyidae (Polychaeta) from Japan. Part 2. The Genera Dentinephtys and Nephtys // Bull. Natn. Sci. Mus., Tokyo, Ser. A. Vol.13. No.2. P.41-77.

Jirkov I.A. 1989. [Bottom fauna of the USSR. Polychaeta] Moscow: MGU Press. 141 p. [in Russian].

Jirkov I.A., Paraketsova N.Yu. 1996. [Review of the genus Micronephthys (Polychaeta, Nephtyidae) from the White Sea] // Zool. zhurn. Vol.75. No.6. P.831-840 [in Russian].

Lee J.H., L.G. Jae 1983. Polychaetous annelids from the Yellow Sea. 1. Family Nephtyidae // Bull. KODRI. Vol.5. No.2. P.19-27.

Lovell L.L 1997. A review of six species of Nephtys (Cuvier, 1817) (Nephtyidae: Polychaeta) described from the Eastern Pacific // Bulletin of Marine Science. Vol.60. No.2. P.350-363.

Lvova T.G. 1976. [Some data on biology of Nephtys minuta Theel in the White Sea] // Problemy Zoologii. Leningrad: ZIN. P.61-63 [in Russian].

Lvova T.G. 1978. [Life time of Nephtys minuta Theel (Annelida, Polychaeta) in the White Sea] // 2nd AllUnion Conference on shelf biology. Sevastopol, 1978, Kiev. P.68-69 [in Russian].

Lvova T.G. 1981. [Life circle and salinity adaptations of Micronephthys minuta Theel (Nephtyidae, Polychaeta) in the White Sea]. Autoreferate of Ph.D thesis. Leningrad: ZIN. 20 p. [in Russian].

Mackie A.S.Y. 2000. Micronephthys oculifera (Polychaeta: Nephtyidae), a remarkable new species from Hong Kong, China // Bulletin of Marine Science. Vol.67. No.1. P.517-528.

Marinov T. 1977. Mnogochetinesti chervei (Polychaeta) // Fauna Bulgaria. Sofia: Bulgarian Academy of Science Press. Vol.6. P.1-258 [in Bulgarian].

Martin D., Lana P., Gil J. 2009. Inermonephtys brasiliensis n. sp. (Polychaeta: Nephtyidae) from SE Brazil, with a redescription of I. palpata Paxton, 1974 // Zoosymposia. No.2. P.165-177.

Nateewathana A., Hylleberg J. 1986. Nephtyid polychaetes from the west coast of Phuket Island, Andaman Sea, Thailand, with description of five new species // Proc. Linn. Soc. N.S.W. Vol.108. No.3. P.195-215.

Noyes G.S. 1980. The biology of Aglaophamus neotenus (Polychaeta: Nephtyidae) a new species from Maine and Canada // Biol. Bull. Marine Biol. Lab., Woods Hole. Vol.158. No.1. P.103-117. 
Ohwada T. 1985a. Prostomium morphology as a criterion for the identification of nephtyid polychaetes (Annelida: Phyllodocida), with reference to the taxonomic status of Aglaophamus neotenus // Publ. Seto Marine Biol.1 Lab. Vol.30. No. 1/3. P.55-60.

Ohwada T. 1985b. Redescription of nephthyid polychaete Aglaophamus minusculus Hartman, 1965 // Proc. Biol. Soc. Wash. Vol.98. No.3. P.604-610.

Pettibone M.H. 1963. Marine polychaete worms of the New England region. I. Aphroditidae through Trochochaetidae // US Nat. Mus. Bull. Vol.227. 356 p.

Pluscheva M., Martin D., Britayev T. 2004. Population ecology of two simpatric polychaetes, Lepidonotus squamatus and Harmothow imbricata (Polychaeta, Polynoidae), in the White Sea // Invertebrate Zoology. Vol.1. No.1. P.65-73.

Rainer S.F. 1984. Nephtys pente sp.nov. (Polychaeta: Nephtyidae) and a key to Nephtys from Northern Europe // J. mar. biol. Ass. UK. Vol.64. No.4. P.899-907.

Rainer S.F. 1989. Redescription of Nephtys assimilis and N. kersivalensis (Polychaeta: Phyllodocida) and a key to Nephtys from Northern Europe // J. mar. biol. Ass. UK. Vol.69. P.875-889.

Rainer S.F. 1990. The genus Nephtys (Polychaeta: Phyllodocida) in northern Europe: redescription of $N$. hystrix and N. incisa // J. Nat. Hist. Vol.24. P.361372.

Rainer S.F. 1991. The genus Nephtys (Polychaeta: Phyllodocida) of northern Europe: a review of species, including the description of $N$. pulchra sp.n. and a key to the Nephtyidae// Helgolander Meeresunters. Vol.45. P.65-96.

Rainer S.F., Hutchings P. 1977. Nephtyidae (Polychaeta: Errantia) from Australia // Rec. Austr. Mus. Vol.31. No.8. P.307-347.
Rainer S.F., Kaly U.L. 1988. Nephthyidae (Polychaeta: Phyllodocida) of Australia: new species from the North West shelf, and a key to Australian species // J. Nat. Hist. Vol.22. P.685-703.

Ravara A., Wiklund H., Cunha M. R., Pleijel F. 2010. Phylogenetic relationships within Nephtyidae (Polychaeta, Annelida) // Zoologica Scripta. Vol.39. P.394-405.

San Martin G. 1982. Una nueva especie de Nephtyidae (Poliquetos: Errantes) del Mediterraneo: Micronephthys maryaen.sp//Cahiers de Biologie Marine. Vol.27. P.427-434.

Theel H.J. 1879. Les Annelides polychetes de la NouvelleZemble // Svensk. Akad. Handl. Bd.16. H.3. P.3-75.

Tzetlin A.B. 1980. [Practical key of the White Sea Polychaeta]. Moscow: MGU Press. 113 p. [in Russian].

Uschakov P.V. 1955. [Polychaetous annelids of the Far Eastern Seas of the USSR] // Opredeliteli po faune SSSR, izdavaemye Zool. Inst. AN SSSR. No.56. 433 p. [in Russian] (translated in English in 1965 by Israel Program Scientific Translating, Jerusalem).

Uschakov P.V., Wu B.-L. 1965. [The Polychaeta Errantia of the Yellow Sea] // Issledovaniya fauny morei. No.3 (11). P.145-258 [in Russian].

Wesenberg-Lund E. 1949. Polychaetes of the Iranian Gulf // Danish Scientific Investigations in Iran. Vol.4. P. 247-400.

Zatsepin V.I. 1948. [Polychaeta] // N.S. Gayevskaya (ed.). Opredelitel' fauny i flory severnykh morei SSSR. Moscow: Vysshaya Shkola Press. P.94-167 [in Russian].

Responsible editor K.G. Mikhailov 